\title{
EVALUATION AND COMPARISON OF OPEN AND CLOSED TIBIA SHAFT FRACTURES IN A QUATERNARY REFERENCE CENTER
}

\author{
COMPARAÇÃO DAS FRATURAS DIAFISÁRIAS DE TIBIA \\ EXPOSTAS E FECHADAS EM UM SERVIÇO QUATERNÁRIO
}

\author{
Alex de Lima Santos ${ }^{1}$, Conrado Tazima Nitta ${ }^{1}$, Guilherme Bonlı ${ }^{1}$, Gustavo Tadeu Sanchez $^{1}$, Marcel Jun Sugawara Tamaoki $^{1}$, \\ FERNANDO BALDY DOS REIS ${ }^{1}$
}

1. Escola Paulista de Medicina da Universidade Federal de São Paulo, São Paulo, SP, Brazil.

\begin{abstract}
Introduction: Tibia shaft fractures are among the most common in orthopedic practice, but Brazilian literature remains limited on the subject. Objective: To evaluate the characteristics of tibia shaft fractures and conduct a comparison between exposed and closed fractures of the tibia. Methods: This comparative prospective study examined all tibia shaft fractures admitted to our services over a twelve-month period. The cases were evaluated according to age, trauma mechanism, sex, associated fractures, treatment, hospital stay, and readmission rate during the six months after discharge. Results: Fifty-three cases met the inclusion criteria. The average age was 36 years (SD 14.3) and $83 \%$ were males $(p<0.001)$. Traffic accidents were responsible for $73.6 \%$ of fractures $(p<0.001)$. Exposed fractures were found in $52.8 \%$ of the cases $(p=0.56)$. When initial treatment consisted of stabilization with external fixation, these cases were more likely to be rehospitalized $(p=0.009)$. Cases of open fracture also had longer hospital stays $(p<0.001)$ and a higher readmission rate $(p=0.028)$. Conclusion: Open fractures are associated with more severe trauma, expressed in longer hospital stays and high rates of readmission. Cases of fracture which were initially treated with external fixation had a higher readmission rate. Level of Evidence II; Prospective comparative study.
\end{abstract}

Keywords: Tibial fractures. Fractures, open. Fractures, closed. Prospective study.

\section{RESUMO}

Introdução: Fratura diafisária de tíbia é uma das fraturas mais comuns na prática ortopédica, porém a literatura brasileira ainda é limitada na sua avaliação. Objetivo: Avaliar as características das fraturas diafisárias de tíbia e realizar uma comparação entre as expostas e fechadas. Material e Métodos: Foi realizado um estudo, prospectivo comparativo por 12 meses, com todas as fraturas diafisárias de tíbia admitidas. Os pacientes foram avaliados nos seguintes critérios: idade, mecanismo de trauma, sexo, fraturas associadas, tratamento, tempo de internação e índice de reinternação nos seis meses subsequentes à alta. Resultados: Foram avaliados 53 casos que se encaixavam nos critérios de inclusão. A idade média dos pacientes avaliados no nosso estudo era de 36 anos (DP14,3), 83\% eram homens $(p<0,001)$. Acidente de tráfego foi responsável por $73,6 \%(p<0,001)$. Lesões expostas foram encontradas em $52,8 \%$ ( $p=0,56)$. O fixador externo, quando utilizado como método de estabilização inicial, apresentou maior índice de reinternação $(p=0,009)$. As lesões expostas apresentaram tempo de internação $(p<0,001)$ e índice de reinternação superior as fechadas $(p=0,028)$. Conclusões: As fraturas expostas estão envolvidas com traumas de maior gravidade, tanto pelo tempo aumentado de internação hospitalar quanto pelo alto índice de reinternação. Fraturas tratadas inicialmente com fixador externo apresentam maior taxa de reinternação. Nível de Evidência II; Estudo prospectivo comparativo.

Descritores: Fraturas de Tíbia. Fraturas expostas. Fraturas fechadas. Estudos prospectivos.

Citation: Santos AL, Nitta CT, Boni G, Sanchez GT, Tamaoki MJS, Reis FB. Evaluation and comparison of open and closed tibia shaft fractures in a quaternary reference center. Acta Ortop Bras. [online]. 2018;26(3):194-7. Available from URL: http://www.scielo.br/aob.

\section{INTRODUCTION}

Tibia shaft fractures are very prevalent in emergency orthopedics services and tend to be associated with a specific patient profile: they usually affect men of economically productive age involved in high-energy trauma. ${ }^{1-3}$ These patients generally cannot return to their work for an extended period of time, and require many medical visits in the interim, generating high social costs. ${ }^{4,5}$
In the specific case of tibial shaft fractures, most studies are found in the foreign literature and suggest trauma mainly related to sports injuries and traffic accidents. ${ }^{2}$ In Brazil, the literature is scarce and the few studies are mostly retrospective, reviewing medical records. It is currently accepted that open fractures have an important relationship with higher-energy trauma, longer treatment time, and higher rates of complications in comparison with closed fractures. ${ }^{6,7}$

All authors declare no potential conflict of interest related to this article. 
Even though these data are already solidly established in the international literature, no Brazilian studies were found that compared open and closed fractures to determine if our epidemiology is similar to that found in the international literature.

This comparison between exposed and closed fractures permits a better understanding of this type of fracture in the Brazilian scenario and consequently informs cost-effective and efficient ideas for acquisition and availability of equipment to be used in orthopedic urgent care, particularly open fractures. It also can act as a guide for preparing preventive measures for traumas which are related to these fractures. The rationale for this study is to present the epidemiological data from patients with tibial fracture who were admitted to our service, and to use these data to compare closed and open fractures according to the evaluated criteria.

\section{MATERIALS AND METHODS}

This observational, descriptive, prospective study was conducted over a period of twelve months (January-December 2016) involving all patients with tibial shaft fractures who were admitted to our service. The study was conducted with the approval of the institutional review board (process number 47573615.2.0000.5505).

The patients were followed throughout hospitalization and the following data were evaluated: age, sex, trauma mechanism, fracture characteristics, associated fractures, treatment method chosen, skin injury, hospital stay, and hospital readmission during the six months following discharge. All patients enrolled in the study signed an informed consent form (ICF).

The fractures lines were evaluated using radiography and classified as $42-\mathrm{A}, 42-\mathrm{B}$, or $42-\mathrm{C}$ according to the $\mathrm{AO}$ classifications, ${ }^{2,8,9}$ while the skin injuries were classified according to Gustillo. ${ }^{7}$ Both the $x$-rays and the skin injuries were photographed and classified by at least two researchers in the study. The information about the treatment performed, hospital stay, and readmission during the following six months was obtained from the medical records. Finally, the remaining items were evaluated by questioning the patient directly. After informed consent form was obtained, all patients over 12 years of age admitted to our service with tibial shaft fractures (AO 42) who did not have a history of previous surgical procedure or tibial fracture were selected.

The statistical analysis was carried out by a professional who did not participate in the study; the confidence interval $(\mathrm{Cl})$ was $95 \%$ and statistical error was set at a maximum of $5 \%(p<0.05)$. Parametric tests were used for the analysis, since the data are quantitative and continuous. No tests were used to verify the normal distribution of the study, since the sample was greater than 30. The SD (standard deviation) is presented along with the mean values.

\section{RESULTS}

Sixty patients with tibial shaft fractures were admitted, but 7 patients were excluded from the study, yielding a total sample of 53 fractures. One patient was excluded from the study for having previously undergone a tibial procedure, and 6 were under 12 years of age. Of the selected patients, $13.2 \%(p<0.001)$ did not receive their treatment at our service because they or their families preferred a transfer to private services. Patients who did not receive treatment from our service were excluded from the evaluation of the hospital stay, treatment received, and readmission.

\section{Sex and age}

The mean age of the patients with tibial fractures was 36.0 years (SD 14.3 years). The mean ages for female and male patients were 38.7 years (SD 17, $p=0.542$ ) and 35.4 years (SD 13.9 years; $p=0.542$ ), respectively. However, this fact showed no statistical significance; 83\% of the cases were male and $17 \%$ female $(p<0.001)$ (Figure 1) (Table 1).

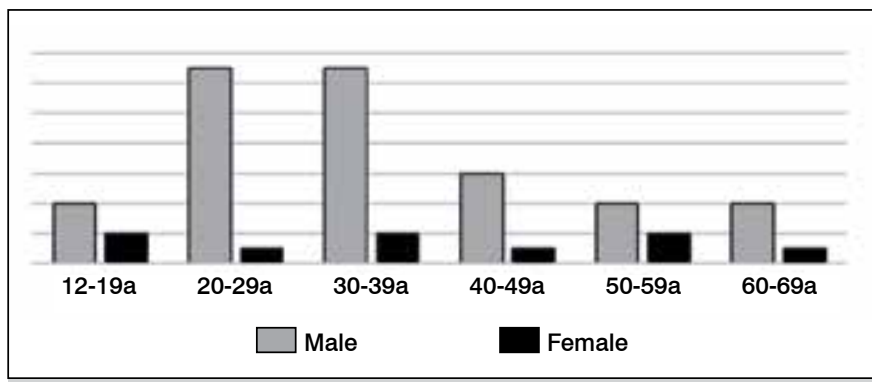

Figure 1. Age and sex ratio.

Table 1. General presentation of the data

\begin{tabular}{|c|c|c|c|}
\hline & & $(\%[n])$ & p-value \\
\hline \multicolumn{2}{|c|}{ Mean age \pm SD (years) } & $36 \pm 14.3$ & \\
\hline \multirow{2}{*}{ Distribution by sex } & Male & $83.00 \%(44)$ & \multirow{2}{*}{$<0.001$} \\
\hline & Female & $17.00 \%(9)$ & \\
\hline \multirow{3}{*}{ AO Classification } & $42-A$ & $66 \%(35)$ & \multirow{3}{*}{$<0.001$} \\
\hline & $42-B$ & $13.2 \%(7)$ & \\
\hline & $42-C$ & $20.8 \%(11)$ & \\
\hline \multirow{2}{*}{ Associated fractures } & Yes & $83 \%(44)$ & \multirow{2}{*}{$<0.001$} \\
\hline & No & $17 \%(9)$ & \\
\hline \multirow{2}{*}{ Exposed bone } & Yes & $52.8 \%(28)$ & \multirow{2}{*}{0.56} \\
\hline & No & $47.2 \%(25)$ & \\
\hline \multirow{4}{*}{ Trauma mechanism } & Traffic accident & $73.6 \%(39)$ & \multirow{4}{*}{$<0.001$} \\
\hline & Falls from Height & $11.3 \%(6)$ & \\
\hline & Sports Trauma & $9.4 \%(5)$ & \\
\hline & Other & $5.7 \%(3)$ & \\
\hline \multicolumn{2}{|c|}{ Hospitalization \pm SD (days) } & $14.8 \pm 16.2$ & \\
\hline \multirow{2}{*}{ Readmission in 6 months } & Yes & $13 \%(9)$ & \multirow{2}{*}{$<0.001$} \\
\hline & No & $87 \%(44)$ & \\
\hline
\end{tabular}

\section{Trauma mechanism and associated injuries}

Traffic accidents, falls from height, sports trauma, and other mechanisms were responsible for $74 \%, 11 \%, 9 \%$, and $6 \%$ of injuries, respectively. $(p<0.001)$ (Table 1$)$ Among the victims of traffic accidents, $55 \%$ were involved in motorcycle accidents, $36 \%$ were hit by a motor vehicle $(p=0.069), 5 \%$ were in a car accident $(p<0.001)$, and $3 \%$ were in bicycle accidents $(p<0.001)$. No statistical correlation was found between traffic accidents or sports trauma and male or female sex $(p=0.25)$

Associated injuries were found in $83 \%$ of cases; $(p<0.001)$ (Table 1$)$ in this group of patients, fibular fracture was found in 95\% of cases $(p<0.001)$, ipsilateral femur fracture in $6.8 \%$ of cases $(p<0.01)$, and forearm fracture also in $6.8 \%$ of cases $(p<0.001)$.

Fracture characteristics, bone exposure, and associated skin injury

Sixty six percent of patients had a simple fracture classified as AO $42-A$, while $13 \%$ had a wedge fracture $(42-B)$, and $21 \%$ had a segmental fracture. $(42-C)(p<0.001)$ (Table1) In terms of skin injury, $53 \%$ of fractures involved bone exposure and $47 \%$ were closed, but this fact was not statistically significant $(P=0.56)$. The fractures were classified as more severe (AO 42-C) were related to open fractures, with statistical significance $(p=0.002)$ (Table 2) Of the open fractures, type IIIA accounted for $82 \%, 11 \%$ were IIIB, and $7 \%$ were IIIC. $(p<0.001)$ (Table 1) No Gustillo classification I or II fractures were documented. 
Table 2. Correlation between open fracture, $A O$ classification, and readmission.

\begin{tabular}{c|c|c|c|c|c|c|c|c}
\hline \multirow{2}{*}{ Open fracture } & \multicolumn{2}{|c|}{ No } & \multicolumn{2}{c|}{ Yes } & \multicolumn{2}{c|}{ Total } & \multirow{2}{*}{$\begin{array}{c}\text { P-value } \\
\text { Comparison }\end{array}$} \\
\cline { 2 - 9 } & N & $\%$ & N & $\%$ & N & $\%$ & \\
\hline \multirow{4}{*}{ AO Classification } & $42 \mathrm{~A}$ & 20 & $80 \%$ & 15 & $54 \%$ & 35 & $66 \%$ & \multirow{2}{*}{0.002} \\
\cline { 2 - 9 } & $42 \mathrm{~B}$ & 5 & $20 \%$ & 2 & $7 \%$ & 7 & $13 \%$ & \\
\cline { 2 - 8 } & $42 \mathrm{C}$ & 0 & $0 \%$ & 11 & $39 \%$ & 11 & $21 \%$ & \\
\hline \multirow{2}{*}{$\begin{array}{c}\text { Readmission } \\
\text { in 6m }\end{array}$} & No & 19 & $100 \%$ & 21 & $78 \%$ & 40 & $87 \%$ & \multirow{2}{*}{0.028} \\
\cline { 2 - 8 } & Yes & 0 & $0 \%$ & 6 & $22 \%$ & 6 & $13 \%$ & \\
\hline
\end{tabular}

\section{Treatment}

Upon admission, all cases of open fracture were immediately subjected to an aggressive protocol involving the following components: intravenous antibiotic therapy, surgical debridement and cleaning, fracture stabilization, and early coverage of soft tissue. Initially, $78 \%$ of the cases were stabilized with external fixation and $22 \%$ with other methods (locked intramedullary nail, amputation, or plaster splint). ( $p<0.001)$ Of the cases initially stabilized with external fixation, $45 \%$ were treated definitively with linear external fixation and $55 \%$ were treated with other methods (circular external fixator, locked intramedullary nail or plate). There was also a statistically significant correlation between the use of external fixation to treat tibial fractures, whether temporary $(p=0.009)$ or definitive $(p=0.031)$, and readmission.

In the closed fractures, $11 \%$ of the cases were treated with external fixation and 89\% with other methods (locked intramedullary nail, conservative treatment, linear external fixation, or plate) $(p<0.001)$.

\section{Hospitalization time and readmission rate}

The cases with open fractures remained in the hospital for approximately 21.5 days (SD 17.9, $p<0.001$ ) and cases with closed fractures remained in the hospital for an average of 5.4 days. (SD 5.6, $p<0.001$ )(Table 2)

In the first six months after discharge, $21 \%$ of cases which initially had open fractures were readmitted $(p=0.028)$. Of the cases that initially had closed fractures, no patients were readmitted. $(p=0.028)$ (Table 2$)$

\section{DISCUSSION}

Epidemiological studies portraying the profile of certain fractures are still rare in Brazil, notably because of the absence of a proper recording system with national reach. In the search for a mechanism with the lowest possible losses in data collection, this study was conducted prospectively throughout 2016 . The patients were evaluated at admission, accompanied throughout hospitalization, and followed considering a chance of readmission during the six months following discharge.

In general, the majority of patients affected by this injury, in our study as well as other series, are men at economically productive age and involved in traffic accidents. ${ }^{1-3}$ The trauma mechanism in our study seems to differ from those found in the literature. In our study, $74 \%(p<0.001 \%)$ of patients were victims of traffic accidents, a number that seems to be higher than the findings of other international studies $(37.5 \%)^{2}$ and very similar to another Brazilian study. $(77 \%)^{3}$
For traffic accidents, the latest recommendations involve a series of public policies that must be carried out on a wide scale with several fronts of intervention. These interventions should be based on measures involving oversight of offenders and implementation of strict penalties, as well as public awareness campaigns. ${ }^{10,11}$ With respect to the fracture characteristics and bone exposure, a statistical significant relationship was seen between open fractures and $42-\mathrm{C}$ type fractures and also between closed fractures and $42-\mathrm{A}$ type fractures. The $\mathrm{AO}$ classification involves a scale that increases in severity, ${ }^{9}$ with $42-\mathrm{C}$ fractures resulting from greater energy than 42-A fractures. This feature explains the relationship between open fractures (more severe injuries) with 42-C type fractures and closed injuries with the 42-A classification.

As for the most frequent treatment for open fractures, external fixation was most commonly used as the initial treatment, with statistical significance. This preference by Brazilian orthopedic physicians in treating open fractures (whether as damage control or even definitively) had already been demonstrated in a previous Brazilian study. ${ }^{12}$ One possible explanation for the extensive use of external fixators as a form of temporary and definitive treatment in Brazil had already been raised by other authors, namely that they are more practical, implant costs are lower, and they are widely available in the public health network.12,13

We also found that patients who received external fixation for initial stabilization of open fractures had a statistically significant higher rate of readmission. This higher rate has already been addressed in the literature and is currently accepted as one of the main disadvantages of external fixation, mainly in comparison with the locked intramedullary nail. ${ }^{6}$ For this particular finding, it should be noted that the external fixation device is removed in an outpatient setting, and therefore does not count as readmission.

Other relevant findings from this study are the longer hospital stay and higher rate of readmission for open fractures (both with statistical significance), which are probably related to the complexity of treating skin injuries and difficulty of definitive treatment. In the specific case of our institution, the prolonged hospitalization is thought to be principally related to the recent crisis our service is facing and consequent difficulty in acquiring materials. The high rate of readmission can be related to the fact that the procedures are mostly performed by resident physicians and also because of the difficult management of skin injuries involved in open fractures. Our study presented some limitations: the follow-up period was short, and did not evaluate clinical and radiological outcomes. However, even with these limitations we were able to present the epidemiological characteristics of our service and thus demonstrate the main limitations of a Brazilian public hospital; the findings of this study can be extrapolated to other services with characteristics similar to our hospital.

\section{CONCLUSION}

Open fractures are associated with more severe trauma, because of the significant relationship between these fractures and 42-C type fractures as well as the increased time of hospitalization and high rate of readmission. Fractures treated initially with external fixation have a higher rate of readmission when compared to other initial stabilization techniques.

AUTHORS' CONTRIBUTIONS: Each author made significant individual contributions to this manuscript. ALS (0000-0002-4063-672X)*: contributed to the substance, concept, and development of the study, collected data, conducted the statistical analysis, and drafted the text; CTN (0000-0003-3043-8727)*: participated in the discussion of the results and drafting the text; GB (0000-0002-4846-9188)* contributed to the substance, concept, and development of the study, as well as the statistical analysis and drafting of the text; GTS (0000-0001-9732-8763)*: participated in the discussion of results, statistical analysis and drafting of the text; MJST (0000-0002-9539-4545)*: participated in the drafting, revision, and final approval of the text; BR (0000-0003-24312634)*: contributed to the substance, concept, and development of the study, as well as the revision and final approval of the text. All authors approved the final version of the manuscript. *ORCID (Open Researcher and Contributor ID). 


\section{REFERENCES}

1. Court-brown CM, Bugler KE, Clement ND, Duckworth AD, Mcqueen MM. The epidemiology of open fractures in adults. A 15-year review. Injury. 2012;43(6):891-7.

2. Court-brown CM, Mcbirnie J. The Epidemiology if tibial fractures. J Bone Joint Surg Br. 1995;77(3): 417-21.

3. Grecco MAS, Junior I do P, Rocha MA, Barros JW. Estudo epidemiológico das fraturas diafisárias de tíbia. Acta Ortop Bras. 2002;10(4):10-7.

4. Busse JW, Bhandari M, Sprague S, Johnson-masotti AP, Gafni A. An economic analysis of management strategies for closed and open grade I tibial shaft fractures. Acta Orthop. 2005;76(5):705-12.

5. Ferreira JC, Albuquerque CSG, Oliveira E, Alves MW, Ferreira RA, Caron M. Estudo comparativo entre aparelho gessado e haste intramedular bloqueada no tratamento da fratura fechada da diáfise da tíbia. Rev Bras Ortop. 2006;41(19):405-10.

6. Bhandari M, Guyatt GH, Swiontkowski MF, Schemitsch EH. Treatment of open fractures of the shaft of the tibia. J Bone Joint Surg Br. 2001;83(1):62-8.

7. Gustilo RB, Mendonza RM, Williams DN. Problems in the management of type III (severe) open fractures: a new classification of type III open fractures. J Trauma. 1984;24(8):742-6.
8. Marsh JL, Slongo T, Agel J, Broderick JS, Creevey W, DeCoster TA et al. Fracture and Dislocation Classification Compendium. J Orthop Trauma. 2007;21(10 Suppl):S1-133.

9. Johner R, Wruhs O. Classification of tibial shaft fractures and correlation with results after rigid internal fixation. Clin Orthop Relat Res. 1983;(178):7-25.

10. Poli de Figueiredo LF, Rasslan S, Bruscagin V, Cruz R, Rocha e Silva M. Increases in fines and driver licence withdrawal have effectively reduced immediate deaths from trauma on Brazilian roads: First-year report on the new traffic code. Injury. 2001;32(2):91-4.

11. Staton C, Vissoci J, Gong E, Toomey N, Wafula R, Abdelgadir J et al. Road traffic injury prevention initiatives: A systematic review and metasummary of effectiveness in low and middle income countries. PLoS One. 2016;11(1):1-15.

12. Balbachevsky D, Belloti JC, Martins CVE, Fernandes HJA, Faloppa F, Reis FB dos. Como são tratadas as fraturas expostas da tíbia no Brasil? Estudo transversal. Acta ortop bras. 2005;13(5):229-32.

13. Cardozo RT, Silva LG, Bragante LA, Rocha MA. Tratamento das fraturas diafisárias da tíbia com fixador externo comparado com a haste intramedular bloqueada. Rev Bras Ortop. 2013;48(2):137-44. 